\title{
Pengembangan Modul Biologi Molekuler Berbasis Learning Cycle $7 E$ untuk Mahasiswa Pendidikan Biologi
}

\author{
Anwari Adi Nugroho ${ }^{1}$, Nur Rokhimah Hanik ${ }^{2}$, Sri Harsono ${ }^{3}$ \\ 1,2,3 Program Studi Pendidikan Biologi, Fakultas Keguruan dan Ilmu Pendidikan, Universitas Veteran \\ Bangun Nusantara Sukoharjo \\ Email: bio_anwary@yahoo.com
}

\begin{abstract}
Abstrak
Penelitian ini bertujuan untuk mengetahui karakteristik modul biologi molekuler berdasarkan Learning Cycle 7E untuk siswa pendidikan biologi dan untuk mengetahui validitas dan kepraktisannya. Studi elaborasi menggunakan metode Borg \& Gall yang dimodifikasi, yaitu pengumpulan informasi dan penelitian, perencanaan, pengembangan awal dari produk, pengujian lapangan awal, revisi produk utama, pengujian lapangan utama, revisi produk operasional. Subyek tahapan uji lapangan utama dalam penelitian ini adalah siswa Semester VII Biologi Pendidikan FKIP Univet Bantara Sukoharjo Tahun Ajaran 2015/2016. Hasil penelitian menunjukkan bahwa modul biologi molekuler berdasarkan Learning Cycle 7E valid dan praktis (feasible). Dalam uji kelayakan dilakukan validasi pakar termasuk validasi ahli material (skor $87.50 \%$, kategori baik), validasi ahli bahasa / keterbacaan (skor 95,83\%, kategori sangat baik), validasi modul ahli (skor 86, 25). \%; kategori bagus). Hasil validasi praktisi (dosen) terhadap modul pembelajaran penilaian skor adalah $87,66 \%$ (praktisi 1) dan $88,33 \%$ (praktisi 2). Penilaian validasi dan praktisi ahli dari semua modul menyediakan kategori yang berkualitas dan praktis. Validasi modul untuk siswa diperoleh skor $84,25 \%$ dengan kualifikasi dan kategori praktis yang baik. Kepraktisan itu menunjukkan bahwa modul biologi molekuler yang berbasis pada Learning Cycle 7E layak untuk dilaksanakan.
\end{abstract}

Kata kunci: Biologi Molekuler; Siklus Belajar; Modul

\section{Development of Molecular Biology Module Based on Learning Cycle 7E for Biology Education Students}

\begin{abstract}
This study aimed to know the characteristic of molecular biology module based on Learning Cycle 7E for biology education students and to know the validity and practicality of it. Elaboration study used modified Borg \& Gall's method, that was research and information collecting, planning, develop preliminary from of product, preliminary field testing, main product revision, main field testing, operational product revision. Subjects of the phase of main field testing in this study were students of Semester VII Biology Education FKIP Univet Bantara Sukoharjo Academic Year 2015/2016. The results showed that the molecular biology module based on Learning Cycle 7E was valid and practical (feasible). In the feasibility test was done expert validation included validation of the material expert (score of $87.50 \%$; good category), validation of the linguist / readability (score of $95.83 \%$; very good category), module expert validation (score of $86,25 \%$; good category). The results of practitioners validation (lecturers) on the score assessment learning module were $87.66 \%$ (practitioner 1 ) and $88.33 \%$ (practitioner 2). Assessment of expert validation and practitioners of all modules provided both qualified and practical category. Module validation for students obtained the score of $84.25 \%$ with good qualification and practical category. Practicality of it showed that the molecular biology module based on Learning Cycle 7E was feasible to be implemented.
\end{abstract}

Keywords: Molecular Biology; Learning Cycle; Module 


\section{PENDAHULUAN}

Biologi molekuler sebagai salah satu mata kuliah biologi memiliki peranan dalam mengembangkan potensi kemampuan berpikir (Mundilarto, 2005). Biologi molekuler merupakan ilmu yang mempelajari cara mencari tahu, memahami alam secara sistematis, obyektif, universal, analitis dan verifikatif sehingga biologi tidak hanya penguasaan kumpulan pengetahuan yang berupa fakta-fakta, konsep-konsep, prinsipprinsip saja tetapi juga merupakan suatu proses penemuan. McCombs \& Miller (2007) menjelaskan bahwa pembelajaran biologi merupakan pembelajaran yang berpusat pada peserta didik, pendidik menyusun strategi pengajaran, pendidik lebih memfasilitasi daripada mengajar langsung, pengajaran berpusat pada peserta didik, pendidik menempatkan perhatian yang lebih banyak pada keterlibatan, inisiatif dan interaksi peserta didik. Permasalahan rendahnya kemampuan kognitif mahasiswa tidak lepas dari pembelajaran mata kuliah biologi molekuler di kelas. Pembelajaran biologi molekuler di kelas dilaksanakan dengan metode ekspositori. Buku teks yang digunakan mahasiswa dan dosen dalam mata kuliah biologi molekuler sebatas buku teks umum dan belum sesuai dengan karakteristik mahasiswa. Sehingga selama pembelajaran biologi molekuler belum ada bahan ajar atau modul yang diterapkan di kelas. Faktor belum adanya modul pembelajaran dapat menyebabkan minimnya pemahaman materi (Riyanto, 2015).

Peraturan Menteri Ristek dan Dikti nomor 44 Tahun 2015 tentang Standar Nasional Pendidikan Tinggi pada Standar Proses Pembelajaran pasal 11 bahwa pembelajaran di perguruan tinggi bersifat interaktif, holistik, integratif, saintifik, kontekstual, tematik, efektif, kolaboratif dan berpusat pada mahasiswa. Berdasarkan pada peraturan tersebut, dosen memiliki kewenangan untuk mendesain pembelajaran yang inovatif agar mendapatkan proses dan hasil pembelajaran yang berkualitas (Mustami, 2009). Salah satu upaya untuk mengatasi permasalahan tersebut adalah dengan pengembangan modul ajar yang berbasis model pembelajaran yang sesuai dengan karakteristik pembelajaran biologi dan sesuai dengan kebutuhan mahasiswa (Nugroho, Sajidan, dan Masykuri, 2014). Pembelajaran biologi tidak dapat dipisahkan dari pemanfaatan bahan ajar biologi sebagai sumber belajar (. Pembelajaran dengan modul biologi diharapkan mahasiswa mampu menguasai produk sains seperti konsepkonsep, menggunakan metode ilmiah untuk menyelesaikan masalah-masalah sains, dan memiliki sikap positif terhadap sains (Toharudin dkk, 2011).

Pembelajaran yang sesuai dengan karakteristik mata kuliah biologi molekuler salah satunya adalah satunya Learning Cycle (LC) $7 E$ (Lawson, 2001). Model Learning Cycle $7 E$ sesuai untuk mengatasi pembelajaran yang kurang aktif, rendahnya penguasaan konsep dan memberi kesempatan pada mahasiswa untuk meningkatkan prestasi belajar (Hasret dan Yalcin, 2006; Polyiem, Nuangchalerm, Wongchantra, 2011; Opas, Suksringarm, Sungseewo, 2009). Pembelajaran dengan Learning Cycle juga dapat membuat pembelajaran menjadi menyenangkan dan meningkatkan minat mahasiswa (Kenealy, 2013).

Pengembangan modul biologi molekuler berbasis Learning Cycle $7 E$ diharapkan memberikan manfaat pada mahasiswa untuk belajar mandiri, efektif dan efisien. Sifat konstruktifisme pada model Learning Cycle 7E memberikan kesempatan kepada dosen untuk memfasilitasi proses belajar mahasiswa, memberikan kesempatan kepada mahasiswa menemukan dan manerapkan ide-ide mereka sendiri, dan mengajar menjadi sadar menggunakan strategi mereka sendiri untuk belajar (Trianto, 2011; Riyanto, 2010). Pengembangan modul biologi molekuler berbasis Learning Cycle $7 E$ terdiri dari 7 langkah pembelajaran menurut Eisenkraft (2003) yaitu tahapan Elicit, engagement, exploration, explanation, elaboration evaluation, extend. Modul berbasis Learning Cycle 7E untuk mahasiswa Semester VI (angkatan 2013) Program Studi Pendidikan Biologi Universitas Veteran Bangun Nusantara Sukoharjo.

\section{METODE PELAKSANAAN}

Penelitian dilakukan di Program Studi Pendidikan Biologi Fakultas Keguruan dan Ilmu Pendidikan Universitas Veteran Bangun Nusantara Sukoharjo. Penelitian dilaksanakan mulai bulan April sampai bulan mei 2016. Penelitian pengembangan menggunakan desain penelitian dan pengembangan (Research and Development, $R \& D$ ) dari Borg \& Gall (1983) yang telah dimodifikasi menjadi 7 langkah yaitu 1) penelitian dan pengumpulan informasi, 2) perencanaan, 3) pengembangan produk, 4) uji 
coba produk awal, 5) revisi produk awal, 6) uji

lapangan terbatas, 7) revisi produk kedua.

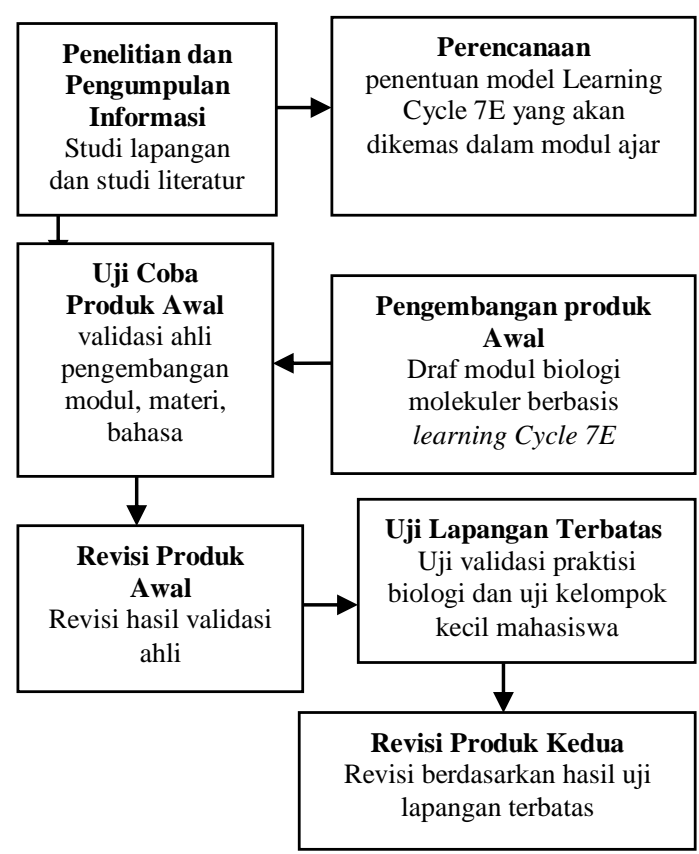

Gambar 1. Prosedur Pengembangan Modul

\section{HASIL DAN PEMBAHASAN}

\section{Tahap Penelitian dan Pengumpulan Informasi.}

Pengembangan modul biologi molekuler diawali dengan pengumpulan informasi berupa studi pustaka dan observasi lapangan. Studi pustaka yang dilakukan meliputi modul ajar dan pembelajaran Learning Cycle 7E. Hasil studi pustaka menunjukkan bahwa pembelajaran biologi dapat dilakukan dengan model pembelajaran yang bersifat konstruktifisme untuk mengupayakan hasil belajar yang baik (Rustaman, 2005; Cakir, 2008). Pada tahap operasi formal, mahasiswa sudah mampu memandang permasalahan secara abstrak, menggunakan berbagai cara untuk merumuskan masalah dan mempertanggungjawabkannya (Hill, 2012; Jarvis, Holford, dan Griffin, 2003). Sehingga model pembelajaran yang dipilih untuk diintegrasikan ke dalam modul adalah Learning Cycle 7E. 7 langkah Learning Cycle $7 E$ yaitu tahapan Elicit, engagement, exploration, explanation, elaboration evaluation, extend (Eisenkraft, 2003). Komponen modul yang akan dikembangkan teridiri dari pendahuluan, inti dan penutup (Sukiman, 2012).

\section{Tahap Perencanaan}

Tahap perencanaan yaitu penyiapan rancangan awal penyusunan modul biologi Molekuler Berbasis Learning Cycle untuk mahasiswa pendidikan biologi dan menyiapkan prosedur penelitian untuk uji kelayakan produk. Kegiatan yang dilakukan pada tahap perencanaan yaitu menentukan tujuan pembelajaran, menyusun produk awal (modul), menentukan Format perangkat pembelajaran, dan menentukan prosedur pengembangan modul ajar.

\section{Pengembangan Produk Awal}

Pengembangan produk awal dilakukan dengan membuat desain modul Learning Cycle 7E pada materi dogma sentra genetik. Materi modul dibagi menjadi 2 bab yaitu materi genetik dan ekspresi gen.

Komponen modul yang dikembangkan antara lain sampul, kata pengantar, daftar isi, Langkah-langkah pada modul, Petunjuk penggunaan modul, Materi Sub bab 1, kegiatan pembelajaran Learning Cycle $7 E$, Soal tes. Sampul : sampul terdiri atas komponen: a) judul modul yaitu modul biologi molekuler (materi genetik dan ekspresi gen); b) gambar/ilustrasi 
DNA; c) keterangan tambahan modul berbasis model Learning Cycle $7 E$, disertai soal kemampuan berpikir kognitif; d) nama pembuat modul adalah Anwari Adi Nugroho, S.Pd., M.Pd. ; e) identitas institusi : Program Studi Pendidikan
Biologi, Fakultas Keguruan dan Ilmu Pendidikan, Universitas Veteran Bangun Nusantara Sukoharjo.

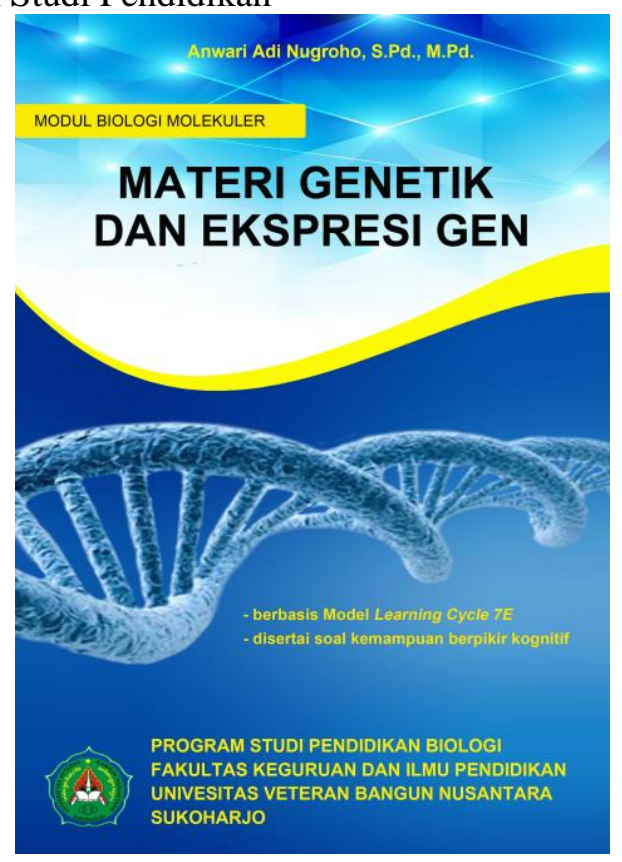

Gambar 2. Sampul Modul Biologi Molekuler Berbasis Learning Cycle $7 E$

Kata pengantar : berisi ucapan syukur kepada Tuhan Yang Maha Esa dan penjelasan mengenai modul berbasis Learning Cycle $7 E$ pada materi dogma sentra genetik. Daftar isi : daftar isi memuat bagian-bagian isi modul dimulai dari halaman judul sampai halaman daftar pustaka yang dilengkapi dengan nomor halaman. Langkah-langkah pembelajaran modul: berisi langkah pembelajaran learning cycle $7 e$. Petunjuk penggunaan modul : berisi arahan dalam penggunaan modul agar pengguna lebih paham dan lebih memaksimalkan dalam pelatihan kemampuan berpikir (kognitif). Materi Sub bab 1 : berisi materi genetik terdiri dari Kromosom, DNA, Gen, dan RNA. Materi sub bab ekspresi gen : berisi tentang replikasi DNA, Transkripsi, dan translasi pada eukariotik dan eukariotik

Komponen selanjutnya yaitu kegiatan pembelajaran Learning Cycle $7 E$ meliputi Elicit, engagement, exploration, explanation, elaboration evaluation, extend. Soal tes: Soal tes bertujuan untuk melatihkan soal berkemampuan berpikir dan mengukur besarnya pemahaman mahasiswa terhadap materi dalam satu kesatuan modul tentang dogma sentra genetik. Soal juga sudah disesuaikan dengan tujuan pembelajaran yang memiliki aspek kemampuan berpikir. Daftar pustaka : berisi referensi yang digunakan di dalam modul. Mahasiswa juga dapat mencari buku-buku yang berada di dalam daftar pustaka untuk membaca dan menambah pengetahuannya lebih luas. Glosarium : berupa penjelasan istilah yang digunakan di dalam modul sehingga mahasiswa memahami beberapa istilah yang menurut mereka asing.

\section{Tahap Uji Coba Produk Awal}

Setelah pembuatan draf modul selesai, langkah selanjutnya adalah Uji Coba Produk Awal. Tahap ini draf modul divalidasi ke ahli. Khabibah (2006) menyatakan bahwa dalam mengetahui tingkat kelayakan model pembelajaran untuk aspek validitas dibutuhkan ahli dan praktisi untuk memvalidasi model pembelajaran yang dikembangkan. Validator modul dibagi menjadi 3 validator, diantaranya adalah validator ahli materi, ahli pengembangan modul dan ahli bahasa/keterbacaan modul. Hasil validasi ahli disajikan pada Tabel 1 . 
Tabel 1. Hasil Validasi Modul oleh Validator Ahli

\begin{tabular}{cccc}
\hline $\begin{array}{c}\text { Validasi } \\
\text { Ahli }\end{array}$ & $\begin{array}{c}\text { Rata- } \\
\text { rata } \\
\text { Skor } \\
(\%)\end{array}$ & Kualifikasi & Kategori \\
\hline 1 & 87,50 & Baik & valid \\
2 & 95,83 & $\begin{array}{c}\text { Sangat } \\
\text { baik }\end{array}$ & valid \\
3 & 86,25 & baik & valid \\
\hline
\end{tabular}

Keterangan validasi ahli : 1. Materi biologi molekuler, 2. Keterbacaan/bahasa, 3. Modul ajar

Tabel 1 menunjukkan hasil validasi ahli materi, bahasa dan modul ajar pada modul biologi molekuler berbasis Learning Cycle 7E diperoleh rata-rata skor validasi ahli materi sebesar 87,50 \% dengan kualifikasi baik. Sedangkan validasi ahli keterbacaan diperoleh rata-rata skor sebesar 95,83\% dengan kualifikasi sangat baik. Validasi ahli modul ajar diperoleh rata-rata skor sebesar $86,25 \%$ dengan kualifikasi baik. (Millah, Budipramana, dan Isnawati: 2012).

\section{Tahap Revisi Produk Awal}

Proses validasi ahli, ahli memberikan saran dan masukkan sebagai perbaikan produk (Krisdiana, 2016). Selama proses validasi ke ahli, terdapat beberapa saran dan masukan sebagai perbaikan untuk modul. Revisi dari ahli materi antara lain : konsep pencantuman gambar pendukung, dan terdapat sumber; penambahan pembahasan tentang percobaan pembuktian hipotesis replikasi DNA semi konservatif; pemisahan materi ekpresi gen pada prokariotik dengan eukariotik. Revisi dari ahli bahasa/keterbacaan antara lain istilah dalam bahasa asing dicetak miring; pada pembahasan komponen replikasi DNA dibuat poin-poin sehingga mudah dipahami; penulisan daftar pustaka disesuaikan dengan format titik, koma, spasi. pemakaian numbering.

Revisi dari ahli modul antara lain langkah pembelajaran Learning Cycle $7 E$ perlu dilengkapi; petunjuk penggunaan modul perlu dilengkapi; cover dilengkapi dengan identitas institusi program Studi Pendidikan Biologi, FKIP, Univet Bantara Sukoharjo. Semua hasil validasi ahli memperoleh kategori tidak perlu direvisi atau valid.

\section{Ujicoba lapangan terbatas}

Ujicoba lapangan terbatas dilaksanakan untuk mengetahui kepraktisan modul dengan melakukan validasi praktisi biologi dan ujicoba kepada mahasiswa yang pernah memperoleh materi biologi molekuler (mahasiswa semester VIII). Validasi modul kepada praktisi biologi dilakukan oleh 2 praktisi (dosen pendidikan biologi) untuk memberikan saran dan masukan serta penilaian terhadap isi modul, penyajian modul dan keterbacaan/bahasa. Hasil validasi praktisi dapat dilihat pada Tabel 2.

Tabel 2. Hasil Validasi Praktisi

\begin{tabular}{cccc}
\hline Praktisi & $\begin{array}{c}\text { Rata- } \\
\text { rata } \\
\text { Skor } \\
(\%)\end{array}$ & Kualifikasi & Kategori \\
& 87,66 & Baik & Praktis \\
\hline 1 & 88,33 & Baik & Praktis \\
\hline
\end{tabular}

Tabel 2. menunjukkan hasil validasi praktisi terhadap isi modul, penyajian modul dan keterbacaan semua dalam kualifikasi baik dan kategori praktis. Hasil validasi modul kepada 10 mahasiswa dapat dilihat pada Tabel 3.

Tabel 3. Hasil Validasi Modul Kepada Mahasiswa

\begin{tabular}{ccc}
\hline $\begin{array}{c}\text { Rata-rata } \\
\text { Skor }(\%)\end{array}$ & Kualifikasi & Kategori \\
\hline 84,25 & Baik & Praktis \\
\hline
\end{tabular}

Tabel 3. menunjukkan hasil validasi modul kepada mahasiswa terhadap isi modul, penyajian modul dan keterbacaan semua dalam kualifikasi baik dan kategori praktis.

\section{Tahap Revisi Produk Kedua}

Selama proses validasi ke praktisi, terdapat beberapa saran dan masukan sebagai perbaikan untuk modul. Revisi dari praktisi (dosen pendidikan biologi) bahwa layout modul biologi molekuler berbasis Learning Cycle $7 E$ diperbaiki agar lebih menarik dan sesuai dengan tema biologi. Selain itu juga disertakan info-info ilmuan biologi yang berkaitan dengan materi dalam modul. Sedangkan revisi dari mahasiswa adalah beberapa gambar perlu diperbesar agar lebih jelas. Kolom untuk jawaban soal lebih diperluas agar jawaban dapat termuat dalam kolom. 
Semua hasil validasi ahli memperoleh kategori tidak perlu direvisi atau praktis. Kepraktisan modul menunjukkan bahwa modul biologi molekuler berbasis Learning Cycle $7 E$ layak untuk diimplementasikan. Pembelajaran dengan modul memiliki beberapa keunggulan. Penggunaan modul berbasis Learning Cycle $7 E$ menururt Hasret dan Yalcin (2006) bahwa pembelajaran Learning Cycle $7 E$ sesuai untuk mengatasi pembelajaran yang kurang aktif dan rendahnya penguasaan konsep. Selain itu, pembelajaran Learning Cycle $7 E$ yang dikemas dalam modul memberikan manfaat pada mahasiswa untuk belajar mandiri, efektif dan efisien. Prastowo (2012) menjelaskan bahwa pembelajaran yang menggunakan modul menurut akan meningkatkan kemampuan mahasiswa untuk belajar secara mandiri tanpa tergantung kehadiran dosen. modul Learning Cycle $7 E$ berisi kegiatan pembelajaran yang mengarahkan mahasiswa untuk menggali pengetahuan awal. melakukan penggalian informasi, evaluasi dan perluasan konsep. Pembelajaran $L C 7 E$ dalam modul juga memberikan kesempatan mahasiswa untuk mengkonstruk pengetahuannya secara mandiri (Brown \& Abell, 2013).

\section{KESIMPULAN}

Kesimpulan yang diperoleh dari penelitian dan pengembangan modul biologi molekuler berbasis Learning Cycle $7 E$ adalah pengembangan modul berbasis biologi molekuler memiliki karakteristik sesuai dengan model Learning Cycle $7 E$ dengan 7 langkah pembelajaran yaitu Elicit, engagement, exploration, explanation, elaboration evaluation, dan extend.

Hasil uji validasi ahli menunjukkan bahwa modul biologi molekuler berbasis Learning Cycle $7 E$ memiliki rata-rata skor validasi ahli materi sebesar 87,50 \% dengan kualifikasi baik. Sedangkan validasi ahli keterbacaan diperoleh rata-rata skor sebesar 95,83\% dengan kualifikasi sangat baik. Validasi ahli modul ajar diperoleh rata-rata skor sebesar $86,25 \%$ dengan kualifikasi baik. Semua hasil validasi ahli memperoleh kategori tidak perlu direvisi atau valid. Hasil validasi praktisi terhadap isi modul, penyajian modul dan keterbacaan semua dalam kualifikasi baik dan kategori praktis. Modul biologi molekuler berbasis Learning Cycle $7 E$ telah valid dan praktis untuk siap diimplementasikan.

\section{DAFTAR PUSTAKA}

Borg, W.R dan Gall, M.D. (1983). Education Research. Fourth Edition. New York: Longman Inc.

Brown, P.L dan Abell, S.K. (2007). Examining The Learning Cycle Science and Children. Columbia: Science Education at the University of Missouri.

Cakir, M. (2008). Constructivist Approaches to Learning in Science and Their Implications for Science Pedagogy: A Literature Review. International Journal of Environmental \& Science Education. Vol. 3, No. 4, 193-206.

Eisenkraft, A. (2003). Expanding the 5E model. The Science Teacher : Research Library.

Hasret, N dan Yalcin, N. 2006. The Effectiveness of The Learning Cycle Model to Increase Students' Achievement In The Physics Laboratory. Journal of Turkish Science Education. 3, Issue 2. Turkish: Turkish Science Education.

Hill, WF. (2012). Theories of Learning (Terjemahan). Bandung: Nusa Media.

Jarvis, P., Holdford, J dan Griffin, C. (2003). The Theori and Practice of Learning. Francis: Taylor \& Francis e-Library.

Khabibah, S. (2006). Pengembangan Model Pembelajaran Matematika dengan Soal Terbuka untuk Meningkatkan Kreativitas Siswa Sekolah Dasar. Disertasi. Surabaya: Program Pasca Sarjana Unesa.

Kenely, KR. (2013). The Effects Of The 5e Learning Cycle On Understanding High School Biology. Montana : Montana State University.

Krisdiana, I. (2016). Pengembangan Perangkat Pembelajaran Pada Matakuliah Statistika Dasar Dengan Metode Problem Based Learning. Jurnal Edukasi Matematika dan Sains (JEMS). IKIP PGRI Madiun. Volume 4, Nomor 1. P-ISSN : 23379049; E-ISSN :2502-4671. 
Lawson, AE. (2001). Using The Learning Cycle to Teach Biology Concepts and Reasoning Patterns. Journal of Biological Education. 35 (4).

McCombs, B. L., \& Miller, L. (2007). Learnercentered classroom practices and assessments: Maximizing student motivation, learning, and achievement. Thousand Oaks, CA: Corwin Press.

Millah, E.S., Budipramana, L.S., dan Isnawati. (2012). Pengembangan Bahan Ajar Materi Bioteknologi di Kelas XII SMA IPIEMS Surabaya Berorientasi Sains, Teknologi, Lingkungan, dan Masyarakat (SETS). Jurnal Bio Edu. 1 (1): 19-24

Mundilarto. (2005). Pendekatan Kontekstual dalam Pembelajaran Sains. $P P M$ Terpadu SMPN 2 Mlati. Yogyakarta: 20 Agustus 2005

Mustami, M.K. (2009). Inovasi Model-Model Pembelajaran Bidang Sains untuk Meningkatkan Hasil Belajar Mahasiswa. Lentera Pendidikan. Volume 12, Nomor 2.

Nugroho, AA., Sajidan, dan Masykuri. (2014). Active Learning in Higher Education (Alihe) pada Pembelajaran Biokimia Melalui Model Problem Based CycleLearning (PBC-L). Prosiding Seminar Nasional Biologi/IPA dan Pembelajarannya. FMIPA Universitas Negeri Malang. ISBN: 978-602-72185$0-5$.

Opas, N.K., Suksringarm, P., Singseewo, A. (2009). Effect of Environmental Education Learning by Using the 7EsLearning Cycle with Multiple Intellegences and The Teacher's Handbook Approaches on Learning Achievement, Critical Thingking and Integrated Science Process Skills of High School (Grade 10) Students. Pakistan Journal of Social Sciences 6 (5) : 292296, 2009. ISSN: 1683-8831.

Riyanto, Y. 2010. Paradigma Baru Pembelajaran. Jakarta : Prenada Media Group.
Permenristekdikti nomor 44 Tahun 2015 tentang Standar Nasional Pendidikan Tinggi (SNPT).

Polyiem, T., Nuangchalerm, P., Wongchantra, P. (2011). Learning Achievement, Science Process Skills, and Moral Reasoning of Ninth Grade Students Learned by 7e Learning Cycle and Socioscientific Issue-based Learning. Australian Journal of Basic and Applied Sciences, 5(10): 257-564, 2011. ISSN 1991-8178.

Prastowo, A. (2012). Panduan Kreatif Membuat Bahan Ajar Inovatif. Yogyakarta: Diva Press.

Riyanto. (2015). Pengembangan Modul Interaktif Pada Pembelajaran Genetika untuk Meningkatkan Hasil Belajar dan Pemahaman Konsep Siswa SMA Islam Batu. Jurnal Edukasi Matematika dan Sains (JEMS). IKIP PGRI Madiun. Vol 3, No 2. P-ISSN: 2337-9049; E-ISSN :2502-4671.

Rustaman, NY. (2005). Stategi belajar Mengajar Biologi. Malang: UM Press.

Sukiman. (2012). Pengembangan Media Pembelajaran. Yogyakarta: PT Pustaka Insan Madani.

Trianto. (2011). Mendesain Model Pembelajaran Inovatif-Progresif: Konsep, Landasan, dan Implementasinya Pada Kurikulum Tingkat Satuan Pendidikan (KTSP). Jakarta: Kencana.

Toharudin, U., Hendrawati, S., dan Rustaman, A. (2011). Membangun Literasi Sains Peserta Didik. Bandung: Pendidikan 